Zeszyty Naukowe Szkoły Głównej Gospodarstwa Wiejskiego

Ekonomika i Organizacja Gospodarki Żywnościowej nr 112, 2015: 63-74

Marta Kawa, Kazimierz Cyran

Uniwersytet Rzeszowski

Katedra Marketingu i Przedsiębiorczości

\title{
Wiedza konsumentów jako determinanta decyzji zakupowych na rynku żywności ekologicznej
}

\section{Wstęp}

Rolnictwo ekologiczne rozwija się dynamicznie na świecie oraz w krajach Unii Europejskiej. W Polsce istnieje duży potencjał dla rozwoju rolnictwa ekologicznego zarówno od strony podaży, jak również od strony popytu. Rosnąca popularność żywności ekologicznej w dużym stopniu wynika ze zmiany zachowania konsumentów, którzy coraz chętniej sięgają po produkty ekologiczne. Rolnictwo ekologiczne jest odpowiedzią na zmieniające się potrzeby konsumentów, którzy są coraz bardziej świadomi, że nieodpowiednie odżywianie może być przyczyną wielu chorób, oraz że żywność powstała w warunkach naturalnych spełnia jego oczekiwania. Dlatego należy prowadzić działania zmierzające do zmiany nawyków żywieniowych od najmłodszych lat, zachęcając do konsumpcji produktów ekologicznych. Trudno jest jednak konkurować z dużymi międzynarodowymi koncernami produkującymi żywność w warunkach przemysłowych, które przeznaczają znaczne środki na promocję swoich wyrobów, zachęcając do konsumpcji estetycznie opakowanych produktów, które nie zawsze pozytywnie wpływają na zdrowie. Alternatywą dla żywności konwencjonalnej jest żywność ekologiczna, która zapewnia bezpieczeństwo zdrowotne z racji naturalnych cech jakie charakteryzują te produkty.

Wśród wielu czynników decydujących o dokonywanych zakupach żywności, kluczem do pożądanych decyzji zakupowych jest odpowiednia wiedza na temat cech żywności ekologicznej i konsekwencji jakie niesie za sobą jej spożywanie. Brak odpowiedniej wiedzy w tym zakresie może zniekształcać decyzje nabywcze, skutkiem których mimo swoistego wyobrażenia, że konsument postępuje słusznie, tak naprawdę będzie dokonywał niewłaściwych wyborów. 
Celem artykułu jest ocena stanu wiedzy na temat żywności ekologicznej oraz identyfikacja wpływu tej wiedzy na decyzje podejmowane przez konsumentów.

Źródłem prezentowanych wyników są badania własne przeprowadzone w III kwartale 2014 roku na próbie 200 respondentów, mieszkańców województwa podkarpackiego. Badaną próbę wyodrębniono, wykorzystując dobór kwotowy, odzwierciedlający strukturę populacji. Przy wyznaczaniu kwot uwzględniono takie cechy respondenta, jak: płeć, wiek (w przedziałach 18-24, 25-39, 40-59, 60 i więcej lat) oraz miejsce zamieszkania (wieś, miasto do 20 tys., miasto 20-50 tys., miasto 50-100 tys. i miasto powyżej 100 tys. mieszkańców) respondentów. $\mathrm{Z}$ uwagi na regionalny zasięg badania, które obejmowało teren województwa podkarpackiego, wyników zawartych w niniejszym opracowaniu nie należy uogólniać na populację generalną.

\section{Czynniki wpływające na wzrost popytu na produkty ekologiczne}

W Polsce rynek produktów ekologicznych jest jeszcze słabo rozwinięty w porównaniu do wielu krajów UE, charakteryzuje się małą dostępnością produktów ekologicznych, szczególnie krajowego pochodzenia oraz w konsekwencji ich wysoką ceną, na co w znacznej mierze mają wpływ pośrednicy. Dlatego potrzebne są działania, które umożliwią rozwój rynku, a w konsekwencji obniżenie cen i większą dostępność tych produktów. W latach 2003-2013 liczba gospodarstw ekologicznych w Polsce wzrosła ponad jedenastokrotnie, z 2286 w 2003 do 26598 w 2013 roku $^{1}$. W Polsce istnieje ogromny potencjał, jeśli chodzi o możliwości upraw ekologicznych, gdyż w 2013 roku powierzchnia użytkowana zgodnie z przepisami o rolnictwie ekologicznym wynosiła około 675 tys. ha, co stanowiło ok. $4 \%$ całej powierzchni użytkowanej rolniczo ${ }^{2}$. Konieczne są również działania umożliwiające podnoszenie wiedzy producentów i konsumentów w zakresie jakości, wartości odżywczych produktów ekologicznych. Ważne jest, aby zwiększyć udział krajowych produktów w sklepach z żywnością ekologiczną. Jeden ze sposobów polega na informowaniu konsumentów o wysokiej wartości odżywczej ekologicznych produktów, szczególnie krajowego pochodzenia [Górski i in. 2014, s. 70].

\footnotetext{
${ }^{1}$ Raport o stanie rolnictwa ekologicznego w Polsce w latach 2011-2012. Inspekcja Jakości Handlowej Artykułów Rolno-Spożywczych, Ramowy Plan Działań dla Żywności i Rolnictwa Ekologicznego w Polsce na lata 2014-2020, Ministerstwo Rolnictwa i Rozwoju Wsi, Warszawa 2014. ${ }_{2}^{2}$ Ramowy Plan Działań dla Żywności i Rolnictwa Ekologicznego w Polsce na lata 2014-2020, Ministerstwo Rolnictwa i Rozwoju Wsi, Warszawa 2014, s. 8.
} 
O dynamicznym rozwoju sektora rynku żywności ekologicznej decyduje stale rosnący popyt, który uwarunkowany jest wieloma czynnikami:

- troską o zdrowie i zachowanie dobrej kondycji,

- modą i dbałością o środowisko,

- zaufaniem konsumentów do dostawców produktów ekologicznych,

- ceną i sytuacją materialną konsumentów,

- preferencjami w zakresie jakości konsumowanej żywności,

- $\quad$ stanem wiedzy w zakresie zasad produkcji ekologicznej ${ }^{3}$.

Współcześni konsumenci przejawiają określone oczekiwania w stosunku do żywności ekologicznej. Produkty te muszą wyróżniać się odpowiednią jakością zdrowotna, powinny być dostępne w preferowanych przez konsumentów miejscach sprzedaży i być oferowane w cenach, które będą odpowiednie dla mniej zamożnych konsumentów.

W 2004 roku, dziesięć lat temu najwięcej wskazań dotyczących preferowanego miejsca zakupu uzyskały sklepy specjalistyczne (56\%), targowiska (25\%), supermarkety (21\%) i rolnicy ekologiczni (19\%) [Tybulski i Żakowska-Biemans 2007].

Rozwojowi popytu na żywność ekologiczną sprzyja coraz większa dostępność tego typu produktów, gdyż żywność ekologiczną włączają do swej oferty nie tylko sieci handlowe, ale coraz częściej również mniejsze sklepy spożywcze.

Sprzedaż produktów ekologicznych w supermarketach i hipermarketach oraz sklepach delikatesowych odbywa się zazwyczaj poprzez umiejscowienie tych produktów na wyodrębnionych półkach lub działach sklepu, często są to produkty pochodzące spoza kraju.

Ważnym kanałem dystrybucji są sklepy ogólnospożywcze, lokalne, osiedlowe, które są w niewielkim stopniu wykorzystywane do sprzedaży produktów ekologicznych. W najbliższych latach można się spodziewać zmian w preferencjach konsumentów dotyczących miejsc zakupu żywności ekologicznej. Wzrośnie popularność sklepów specjalistycznych oferujących wyłącznie produkty rolnictwa ekologicznego, konieczne jest jednak znaczne poszerzenie i zróżnicowanie asortymentu polskich produktów ekologicznych.

$\mathrm{Z}$ badań prowadzonych przez $\mathrm{S}$. Żakowską-Biemans wynika, że od kilku lat obserwuje się znaczący wzrost liczby sklepów oferujących żywność ekologiczną zarówno w handlu tradycyjnym, jak i elektronicznym. Ważne są również inicjatywy służące skróceniu drogi między konsumentem i producentem, np. poprzez specjalistyczne targowiska, rynki hurtowe, co przyczyniłoby się do eliminacji pośredników, a przez to obniżenie cen produktów ekologicznych. Tworzenie grup producentów rolnych umożliwiłoby realizację tego typu inicjatyw.

\footnotetext{
${ }^{3}$ Ramowy Plan Działań dla Żywności i Rolnictwa Ekologicznego w Polsce na lata 2014-2020, Ministerstwo Rolnictwa i Rozwoju Wsi, Warszawa 2014, s. 11-12.
} 
Z badań prowadzonych przez M. Lemanowicz wynika, że głównymi motywami zakupu żywności ekologicznej okazały się: przekonanie konsumentów, że żywność ekologiczna jest zdrowa, nie posiada szkodliwych substancji oraz dbałość o zdrowie swoje i bliskich. Najczęstszym powodem, przez który konsumenci rezygnują z zakupu żywności ekologicznej, dla ponad połowy respondentów była cena oraz trudny dostęp do żywności ekologicznej [Lemanowicz 2014, s. 1114]. Wysokie ceny produktów ekologicznych sprawiają, że nie wszystkie grupy społeczne mogą pozwolić sobie na ich zakup [Chotkowski i Czerwinska 2010, s. 164].

Badania przeprowadzone przez Kucińską w 2008 roku wskazały, że poziom wiedzy konsumentów na temat produktów pochodzących z rolnictwa ekologicznego był niski. Przyczyną takiego stanu była niedostateczna informacja w mediach oraz zbyt skomplikowany sposób znakowania żywności ekologicznej. Konsumenci chętnie kupowaliby produkty ekologiczne, o ile byłyby one łatwiej dostępne, lepiej znakowane i tańsze. Głównym motywem spożywania żywności ekologicznej była troska o własne zdrowie i członków najbliższej rodziny [Kucińska 2009, s. 164]. Źródła wiedzy konsumentów o rolnictwie i produktach ekologicznych to głównie media, takie jak Telewizja Polska, prasa oraz coraz częściej Internet.

Rolnictwo ekologiczne przyczynia się do zwiększania na rynku produktów o wysokiej jakości, coraz częściej poszukiwanych przez konsumentów. Jednak pojedynczy producent nie jest $\mathrm{w}$ stanie wprowadzić swoich produktów na rynek. Dlatego potrzebne są wspólne działania wprowadzania produktów do obrotu, wspólny marketing i promocja oraz dostosowanie oferty do zmieniających się potrzeb i oczekiwań konsumentów.

Celem głównym Ramowego Planu Działań dla Żywności i Rolnictwa Ekologicznego w Polsce na lata 2014-2020 jest rozwój rolnictwa ekologicznego i żywności ekologicznej poprzez ${ }^{4}$ :

1) Zwiększenie konkurencyjności rolnictwa ekologicznego oraz wzrost podaży żywności ekologicznej na rynku.

2) Stymulowanie rozwoju przetwórstwa produktów ekologicznych.

3) Dywersyfikacja oraz wzmocnienie kanałów dystrybucji.

4) Wzrost wiedzy konsumentów na temat rolnictwa i żywności ekologicznej.

5) Podniesienie poziomu współpracy pomiędzy podmiotami działającymi w obszarze rolnictwa ekologicznego.

6) Włączenie organów administracji rządowej i samorządowej.

\footnotetext{
${ }^{4}$ Ramowy Plan Działań dla Żywności i Rolnictwa Ekologicznego w Polsce na lata 2014-2020, Ministerstwo Rolnictwa i Rozwoju Wsi, Warszawa 2014, s. 29-30.
} 
7) Utrzymanie wysokiego poziomu systemu kontroli i certyfikacji produktów ekologicznych.

Z badań prowadzonych przez TNS Polska wynika, że osoby kupujące żywność ekologiczną niekoniecznie kojarzą ją z żywnością certyfikowaną. Potwierdzeniem może być niska znajomość unijnego oznaczenia żywności ekologicznej (ekoliść). Brak wiedzy na temat korzyści, jakie dostarcza żywność ekologiczna w porównaniu do żywności konwencjonalnej oznacza brak uzasadnienia dla zwiększenia wysiłku w celu dotarcia do takiej żywności i zapłacenia za nią wyższej ceny niż za produkty nieekologiczne [Nestorowicz i Pilarczyk 2014, s. 589]. Dlatego dla rozwoju rynku żywności ekologicznej bardzo ważne jest podnoszenie poziomu wiedzy konsumentów na temat właściwości, jakości oraz oznaczenia żywności ekologicznej.

\section{Wiedza jako determinanta decyzji zakupowych}

Zachowania konsumentów na rynku produktów ekologicznych zależą od wielu czynników. Determinuje je przede wszystkim poziom świadomości ekologicznej, poziom dochodów, wiedzy i działania marketingowe. Jednym z kluczowych czynników motywujących konsumentów do zakupu produktów ekologicznych jest ich stan świadomości ekologicznej.

Świadoma konsumpcja to inaczej podjęcie decyzji o zakupie danego towaru spożywczego w oparciu o możliwie pełne informacje. Jest to świadomość, że każdorazowy wybór, jakiego dokonuje konsument w trakcie robienia zakupów, niesie za sobą pewne konsekwencje zarówno ekologiczne, ekonomiczne, jak i społeczne. Podstawą trafnych decyzji nabywczych jest odpowiedni stan wiedzy, jakim powinien dysponować świadomy konsument po to, by nie szkodzić swoimi decyzjami sobie i innym. W celu weryfikacji znaczenia wiedzy w kształtowaniu zachowań nabywczych na rynku produktów ekologicznych analizie poddano poziom wiedzy w zakresie tych produktów. Podstawą stopniowania wiedzy była samoocena dokonana przez badanych respondentów (rys. 1).

Z przeprowadzonych badań wynika, że stan wiedzy na temat produktów ekologicznych jest niski. Zaledwie co dziesiąty pytany o znajomość produktów ekologicznych i ich charakterystyczne cechy ocenił swoją wiedzę na bardzo dobrym poziomie. Blisko połowa badanych przyznała, że ma wprawdzie wiedzę o istnieniu takich produktów, ale zakres posiadanej w tym obszarze wiedzy określić należy jako niski. $Z$ kolei $1 / 5$ pytanych nie dysponuje praktycznie żadną wiedzą w zakresie ekologicznych produktów żywnościowych.

Stan wiedzy dotyczącej ekologicznych produktów żywnościowych uzależniony jest od cech społeczno-demograficznych respondentów (tab. 1). 


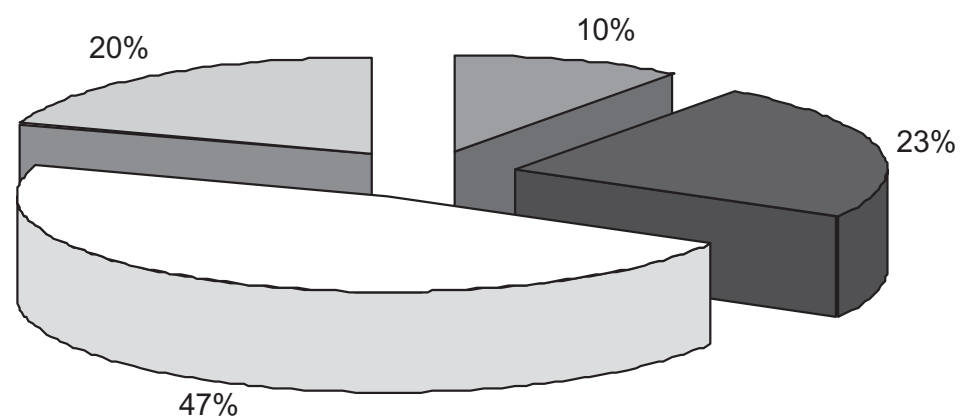

$\square$ bardzo dobra $\square$ dobra $\square$ dostateczna $\square$ niedosteteczna

\section{Rysunek 1}

Stan wiedzy badanych respondentów na temat produktów ekologicznych

Źródło: Obliczenia na podstawie badań własnych.

\section{Tabela 1}

Stan wiedzy badanych respondentów na temat produktów ekologicznych z uwzględnieniem wybranych cech respondentów [\%]

\begin{tabular}{|c|c|c|c|c|c|c|c|c|c|}
\hline \multirow{2}{*}{ Lp. } & \multirow{2}{*}{$\begin{array}{c}\text { Wiedza na temat } \\
\text { produktów ekologicznych }\end{array}$} & \multicolumn{2}{|c|}{ Płeć } & \multicolumn{5}{|c|}{ Wiek } & \multicolumn{2}{c|}{$\begin{array}{c}\text { Miejsce } \\
\text { zamieszkania }\end{array}$} \\
\cline { 3 - 11 } & & $\mathrm{M}$ & $\mathrm{K}$ & $18-24$ & $25-39$ & $40-59$ & 60 i więcej & wieś & miasto \\
\hline 1 & Bardzo dobra & 11,1 & 9,1 & 16,7 & 4,3 & 9,1 & 15,0 & 16,0 & 5,7 \\
\hline 2 & Dobra & 33,3 & 15,2 & 33,3 & 30,4 & 29,1 & 20,0 & 20,0 & 25,7 \\
\hline 3 & Dostateczna & 44,4 & 48,5 & 33,3 & 39,1 & 52,7 & 45,0 & 52,0 & 42,9 \\
\hline 4 & Niedostateczna & 11,1 & 27,3 & 16,7 & 26,1 & 9,1 & 20,0 & 12,0 & 25,7 \\
\hline
\end{tabular}

Źródło: Obliczenia na podstawie badań własnych.

Z badań wynika, że zdecydowanie większą wiedzę z zakresu produktów ekologicznych posiadają mężczyźni. Przejawia się to większym udziałem mężczyzn deklarujących bardzo dobrą i dobrą znajomość produktów ekologicznych, jak również bardzo niskim udziałem przedstawicieli tej grupy, których wiedza jest niedostateczna. Większą świadomością w zakresie znajomości produktów ekologicznych charakteryzują się ludzie młodzi. Powiązane jest to zapewne z etapem kształcenia jaki towarzyszy lub towarzyszył przedstawicielom tej grupy. Okres nauki i kształcenia to czas, w którym młodzi ludzie zdobywają różnorodną wiedzę, w tym wiedzę z profilaktyki odżywiania i dbałości o zdrowie. Problem ten jest szczególnie mocno akcentowany w czasie rozwijających się problemów nadwagi i chorób cywilizacyjnych, będących skutkiem niewłaściwego odżywiania. 
Podobny poziom wiedzy w zakresie produktów ekologicznych deklarują przedstawiciele najstarszej grupy wiekowej. Ludzie starsi częściej zwracają uwagę na zdrowotność spożywanych produktów, gdyż te w dużej mierze decydują o dolegliwościach zdrowotnych jakie występują w określonym wieku. Postępując tym tokiem myślenia, można potwierdzić duży, dodatni wpływ żywności ekologicznej na kondycję zdrowotną spożywających te produkty osób.

Najmniejszą świadomością charakteryzują się respondenci w przedziale wiekowym 25-39 lat. Przedstawiciele tej grupy to młodzi, zdrowi ludzie, często zapracowani i nie mający czasu na troskę o zdrowe odżywianie.

Uzyskane dane wskazują również na przewagę mieszkańców wsi w znajomości produktów ekologicznych. Potwierdza to zarówno wyższy od mieszkańców miast udział reprezentantów ze wsi posiadających dużą wiedzę w badanym zakresie, jak również niższy udział przedstawicieli tych społeczności deklarujących brak wiedzy w tym zakresie.

Analizowany stan wiedzy w zakresie produktów ekologicznych determinuje cechy żywności, jakie powinny charakteryzować żywność ekologiczną (tab. 2).

\section{Tabela 2}

Stan wiedzy konsumentów na temat produktów ekologicznych a wymagania, jakie powinna spełniać żywność ekologiczna [\%]

\begin{tabular}{|c|c|c|c|c|c|c|}
\hline \multirow[b]{2}{*}{ Lp. } & \multirow[b]{2}{*}{$\begin{array}{c}\text { Główne wymagania } \\
\text { stawiane żywności ekologicznej }\end{array}$} & \multirow[b]{2}{*}{ Ogółem } & \multicolumn{4}{|c|}{$\begin{array}{l}\text { Wiedza respondentów na temat } \\
\text { żywności ekologicznej }\end{array}$} \\
\hline & & & 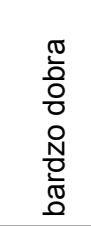 & $\begin{array}{l}\frac{\pi}{0} \\
\frac{0}{0} \\
\frac{0}{0}\end{array}$ & $\begin{array}{l}\frac{\pi}{N} \\
\mathbb{N} \\
\mathbb{d} \\
\mathbb{N} \\
0 \\
0 \\
0\end{array}$ & $\begin{array}{l}\mathbb{0} \\
\stackrel{N}{N} \\
\Phi \\
\frac{\Phi}{\pi} \\
\frac{\pi}{00} \\
\frac{0}{0} \\
\frac{.0}{C}\end{array}$ \\
\hline 1 & $\begin{array}{l}\text { Wyprodukowana w naturalny sposób } \\
\text { bez nawozów i dodatków chemicznych }\end{array}$ & 20,8 & 27,8 & 19 & 24,4 & 11,1 \\
\hline 2 & Wyprodukowana tradycyjnie & 11,2 & 5,6 & 4,8 & 14,6 & 13,9 \\
\hline 3 & Wolna od konserwantów & 22,5 & 16,7 & 21,4 & 23,2 & 25 \\
\hline 4 & $\begin{array}{l}\text { Mało przetworzona, z krótszym okresem } \\
\text { przydatności do spożycia }\end{array}$ & 10,7 & 22,2 & 11,9 & 8,5 & 8,3 \\
\hline 5 & Nieszkodliwa dla zdrowia & 9,6 & 5,6 & 11,9 & 7,3 & 13,9 \\
\hline 6 & Odpowiednio oznakowana i atestowana & 6,7 & 5,6 & 7,1 & 6,1 & 8,3 \\
\hline 7 & Bogata w składniki odżywcze & 11,2 & 5,6 & 14,3 & 13,4 & 5,6 \\
\hline 8 & Wysokie walora smakowe & 5,6 & - & 7,1 & 2,4 & 13,9 \\
\hline 9 & Atrakcyjny wygląd & 1,7 & 11,1 & 2,4 & - & - \\
\hline
\end{tabular}

Źródło: Obliczenia na podstawie badań własnych. 
Najczęściej wymienianym kryterium, jakie powinna spełniać żywność ekologiczna jest brak konserwantów w składzie produktów. Na drugim miejscu respondenci wskazywali na naturalne metody produkcji, bez nawozów i środków podnoszących wydajność produkcji. Kolejne wymagania dotyczyły tradycyjnych metod produkcji i zasobności w składniki odżywcze. Najmniejsze znaczenie dla konsumentów nabywających ekologiczne produkty żywnościowe ma atrakcyjny wygląd produktu. Wprowadzenie do omawianej analizy kryterium poziomu wiedzy respondentów na temat produktów ekologicznych dostarcza nowych wniosków. Najlepiej wyedukowani respondenci jako najważniejsze kryterium produktu ekologicznego podają naturalny sposób produkcji, bez dodatków chemicznych. Bardzo ważne kryterium dla tej grupy stanowi niski poziom przetworzenia i krótki okres przydatności do spożycia. Opisane w ten sposób wymagania potwierdzają kompetencje respondentów, którzy są świadomi, że warunkiem uzyskania dobrych zdrowych produktów jest posiadanie dobrych surowców, a to warunkuje proces ich wytwarzania. Ponadto im bardziej przetworzone produkty i dłuższy okres ich trwałości, tym większe jest prawdopodobieństwo ingerowania w skład produktu.

W miarę spadku poziomu wiedzy na temat żywności ekologicznej obserwuje się przesuwanie wymogów stawianych żywności ekologicznej na inne obszary. Najsłabiej zorientowani nabywcy wprawdzie mocno akcentują warunek braku konserwantów w tych produktach, ale zwracają również uwagę na inne cechy żywności, w tym brak niekorzystnego wpływu na zdrowie, wysokie walory smakowe czy tradycyjne metody produkcji.

Poziom wiedzy z zakresu żywności ekologicznej znajduje przełożenie na decyzje nabywcze konsumentów. Przejawami tych zachowań są czynniki decydujące w największym stopniu o wyborze omawianych produktów (tab. 3).

Największy wpływ na decyzje zakupu produktów ekologicznych ma świeżość produktów, ich walory smakowe i zapachowe oraz wartość odżywcza. Mały wpływ na decyzje zakupowe wywierają natomiast takie czynniki jak wygląd, cena czy kraj pochodzenia. $Z$ uzyskanych danych wynika, że konsumenci charakteryzujący się wyższym poziomem wiedzy na temat produktów ekologicznych przywiązują więcej uwagi w swoich decyzjach zakupowych do cech zdrowotnych produktu, akcentując znaczenie wartości odżywczych i świeżości produktów. Spadkowi zasobu wiedzy jakim dysponują nabywcy towarzyszy zmiana wagi czynników analizowanych, w tym wzrost znaczenia walorów smakowych i zapachowych oraz wzrost znaczenia ceny jako czynnika determinującego wybór ekologicznych produktów żywnościowych.

Poziom świadomości dotyczącej cech żywności ekologicznej wpływa również na preferencje konsumentów dotyczące wyboru miejsca dokonywania zakupu produktów żywnościowych (tab. 4). 
Tabela 3

Stan wiedzy konsumentów na temat produktów ekologicznych a czynniki decydujące o wyborze produktów ekologicznych [\%]

\begin{tabular}{|c|c|c|c|c|c|c|}
\hline \multirow[b]{2}{*}{ Lp. } & \multirow[b]{2}{*}{$\begin{array}{l}\text { Czynniki w największym stopniu } \\
\text { decydujące o wyborze produktów } \\
\text { ekologicznych }\end{array}$} & \multirow[b]{2}{*}{ Ogółem } & \multicolumn{4}{|c|}{$\begin{array}{c}\text { Wiedza respondentów na temat } \\
\text { żywności ekologicznej }\end{array}$} \\
\hline & & & 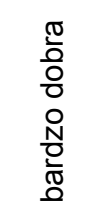 & $\frac{\pi}{\frac{0}{0}}$ & $\begin{array}{l}\frac{\pi}{N} \\
\text { D } \\
\frac{\Phi}{\pi} \\
\frac{\pi}{0} \\
0\end{array}$ & 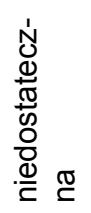 \\
\hline 1 & Świeżość & 27,5 & 27,8 & 31,7 & 27,5 & 23,3 \\
\hline 2 & Walory smakowe i zapachowe & 26,2 & 22,2 & 22,8 & 24,7 & 36,7 \\
\hline 3 & Cena & 5,1 & - & 4,9 & 5,8 & 6,5 \\
\hline 4 & Wartość odżywcza & 24,3 & 27,8 & 24,4 & 21,7 & 23,5 \\
\hline 5 & Wygląd & 2,9 & 5,6 & 2,4 & 2,8 & 3,3 \\
\hline 6 & Przyzwyczajenie & 8,3 & 11,1 & 8,9 & 10,1 & 3,3 \\
\hline 7 & Kraj pochodzenia & 5,7 & 5,6 & 4,9 & 7,2 & 3,3 \\
\hline
\end{tabular}

Źródło: Obliczenia na podstawie badań własnych.

\section{Tabela 4}

Stan wiedzy konsumentów na temat produktów ekologicznych a miejsce, w którym dokonują zakupu produktów ekologicznych [\%]

\begin{tabular}{|c|c|c|c|c|c|c|}
\hline \multirow[b]{2}{*}{ Lp. } & \multirow[b]{2}{*}{$\begin{array}{l}\text { Miejsca, gdzie konsumenci } \\
\text { najczęściej kupują produkty } \\
\text { ekologiczne }\end{array}$} & \multirow[b]{2}{*}{ Ogółem } & \multicolumn{4}{|c|}{$\begin{array}{c}\text { Wiedza z zakresu żywności } \\
\text { ekologicznej }\end{array}$} \\
\hline & & & 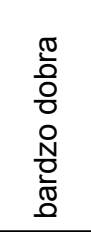 & $\begin{array}{l}\text { 뮤 } \\
\text { 응 }\end{array}$ & 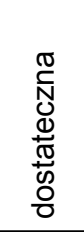 & 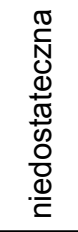 \\
\hline 1 & Sklep specjalistyczny & 38,3 & 58,4 & 28,6 & 39,3 & 33,3 \\
\hline 2 & Sklep wielkopowierzchniowy & 23,3 & 16,7 & 21,4 & 21,9 & 41,7 \\
\hline 3 & Targowisko, bazar & 21,7 & 4,1 & 28,6 & 24,6 & 8,3 \\
\hline 4 & Bezpośrednio u producenta & 15,0 & 20,8 & 21,4 & 10,7 & 12,5 \\
\hline 5 & Sklep internetowy & 1,7 & - & - & 3,6 & 4,2 \\
\hline
\end{tabular}

Źródło: Obliczenia na podstawie badań własnych.

Najczęściej wybieranym miejscem zakupu produktów ekologicznych są sklepy specjalistyczne, w których konsumenci nabywają blisko 40\% spożywanej żywności ekologicznej. Na drugim miejscu pod względem zaopatrzenia w zdrową żywność znajdują się sklepy wielkopowierzchniowe oraz tar- 
gowiska i bazary. Najmniejsze znaczenie w dystrybucji omawianej żywności odgrywają sklepy internetowe. Pomimo rosnącej popularności tego kanału dystrybucji za jego pośrednictwem do konsumentów trafia niecałe $2 \%$ produktów ekologicznych.

Podobnie jak w przypadku wcześniejszych analiz, czynnikiem różnicującym wybór miejsca zakupu żywności ekologicznej jest stan wiedzy konsumentów. Najlepiej zorientowani konsumenci świadomie wybierają sklepy specjalistyczne jako miejsca zakupu gwarantujące im zakup dobrych produktów. Małym zainteresowaniem wśród omawianej grupy respondentów cieszą się natomiast zakupy na targowiskach i bazarach oraz poszukiwanie żywności ekologicznej w sklepach wielkopowierzchniowych. Dla konsumentów z niższym poziomem wiedzy sklepy specjalistyczne również są podstawowym miejscem zakupu żywności ekologicznej, chociaż wielkość zakupów realizowanych w tych miejscach jest zdecydowanie mniejsza. Na znaczeniu zyskują natomiast sklepy wielkpowierzchniowe, w których zakupy zdrowej żywności realizuje ponad $40 \%$ respondentów, posiadających najsłabszą wiedzę z zakresu żywności ekologicznej.

\section{Podsumowanie}

Rynek żywności ekologicznej w Polsce rozwija się dość dynamicznie. Dużym potencjałem są polscy producenci żywności ekologicznej, których liczba w latach 2003-2013 wzrosła ponad jedenastokrotnie. Rosnąca wiedza społeczeństwa w zakresie wpływu rolnictwa ekologicznego na środowisko oraz cech i zalet żywności ekologicznej przyczynia się do wzrostu popytu na produkty ekologiczne.

Przeprowadzone na terenie województwa podkarpackiego badania wskazują, że poziom wiedzy społeczeństwa w zakresie znajomości cech żywności ekologicznej jest bardzo niski. Najwyższą świadomością w tym zakresie odznaczają się mężczyźni, ludzie młodzi oraz mieszkańcy wsi. Wysokiemu poziomowi wiedzy towarzyszą najbardziej racjonalne oceny czynników determinujących zachowania nabywcze. $Z$ kolei brak wystarczającej wiedzy polskich konsumentów powoduje błędne definiowanie cech produktów ekologicznych, co często skutkuje niewłaściwymi decyzjami nabywczymi.

W związku z tym konieczne jest podejmowanie działań informacyjnych, promocyjnych i edukacyjnych, które przyczynią się do podniesienia poziomu wiedzy o zaletach żywności ekologicznej i kreowania odpowiednich zachowań konsumentów. 


\section{Literatura}

CHOTKOWSKI J., CZERWINSKA M., 2010: Instrumenty marketingu $w$ rolnictwie ekologicznym, Zeszyty Naukowe Szkoły Głównej Gospodarstwa Wiejskiego w Warszawie. Polityki Europejskie, Finanse i Marketing 03(52), 160-268.

GÓRSKI J., STANISZEK P., KAZIMIERCZAK R., REMBIAŁKOWSKA E., 2014: The evaluation of the range of organic food from polish annd foreign producers In the selected retail stores In Piaseczno and its vicinity, Journal of Research and Applications in Agricultural Engineering, 59(3), 70-75.

KOCISZEWSKI K., 2014: Perspektywy rozwoju rolnictwa ekologicznego w świetle wyników badań gospodarstw konwencjonalnych, Journal of Agribusiness and Rural Development 1(31), 59-68.

KUCIŃSKA K., 2009: Poziom wiedzy o żywności ekologicznej wśród mieszkańców Warszawy, Journal of Research and Applications in Agricultural Engineering 54(3), 164-172.

LEMANOWICZ M. 2014: Żywność ekologiczna - innowacyjny trend w zachowaniu konsumentów, Marketing i Rynek 8, 1110-1115.

NESTOROWICZ R., PILARCZYK B., 2014: Wyzwania wobec komunikacji marketingowej na rynku żywności ekologicznej w Polsce $-w$ świetle badań konsumentów, Marketing i Rynek 8, 583-589.

Ramowy Plan Działań dla Żywności i Rolnictwa Ekologicznego w Polsce na lata 2014-2020, Ministerstwo Rolnictwa i Rozwoju Wsi, Warszawa 2014, s. 11-12.

Raport o stanie rolnictwa ekologicznego w Polsce w latach 2011-2012. Inspekcja Jakości Handlowej Artykułów Rolno-Spożywczych.

TYBULSKI J., ŻAKOWSKA-BIEMANS S., 2007: Wprowadzenie do rolnictwa ekologicznego, Wydawnictwo SGGW, Warszawa, s. 30-48.

\section{Abstrakt}

W Polsce żywność ekologiczna cieszy się rosnącym zainteresowaniem konsumentów przyczyniając się do dynamicznego rozwoju tego rynku. Celem artykułu jest określenie wpływu poziomu wiedzy konsumentów na temat produktów ekologicznych na decyzje zakupowe. $Z$ przeprowadzonych badań wynika, że stan wiedzy na temat żywności ekologicznej jest nadal zbyt niski. Poziom wiedzy determinuje właściwe określenie cech żywności jakie powinny charakteryzować żywność ekologiczną. Z badań wynika, że konsumenci charakteryzujący się wyższym poziomem wiedzy na temat produktów ekologicznych jako najważniejsze kryterium produktu podają naturalny sposób produkcji, bez dodatków chemicznych oraz przywiązują większą wagę do cech zdrowotnych takich jak wartość odżywcza i świeżość produktów. Ważne są działania zmierzające do podnoszenia poziomu wiedzy i zwiększenia zainteresowania ekologicznymi produktami żywnościowymi.

Słowa kluczowe: żywność ekologiczna, rolnictwo ekologiczne, zachowanie konsumenta, wiedza 


\title{
Consumers' knowledge as a determinant of purchasing decisions on the organic food market
}

\begin{abstract}
In Poland, a growing consumer interest in organic food is observed, contributing to the development of this market. The aim of this article is to determine the influence of the level of consumer awareness of organic products on the purchasing decisions. The study shows that the state of knowledge about organic food is still too low. The level of knowledge determines appropriate defining the characteristics of organic food. The research shows that consumers characterized by higher level of knowledge on organic products, state that the most important product criterion is a natural way of production, without chemical additives. They pay more attention to health characteristics such as nutritional value and freshness of the products. The efforts to raise the consumers' awareness and increase their interest in organic food products is also important.
\end{abstract}

Key words: organic food, organic farming, consumer behavior, knowledge 